\title{
Examination of Pre-Service Science Teachers' Conceptual Perceptions and Misconceptions about Photosynthesis
}

\author{
Ferhat Karakaya $^{1 *}$, Mehmet Yilmaz ${ }^{2}$, Elvan Ince Aka ${ }^{2}$
}

\author{
${ }^{1}$ Yozgat Bozok University, Yozgat, TURKEY \\ ${ }^{2}$ Gazi University, Gazi Faculty of Education, Ankara, TURKEY \\ ^Corresponding Author: ferhatk26@gmail.com
}

Citation: Karakaya, F., Yilmaz, M., \& Aka, E. I. (2021). Examination of Pre-Service Science Teachers' Conceptual Perceptions and Misconceptions about Photosynthesis. Pedagogical Research, 6(4), em0104. https://doi.org/10.29333/pr/11216

\begin{tabular}{|c|c|}
\hline ARTICLE INFO & ABSTRACT \\
\hline Received: 9 Jul. 2021 & Biology, known as the science of life in its most general definition, is one of the branches of science closest to \\
\hline Accepted: 25 Aug. 2021 & $\begin{array}{l}\text { individuals due to the subjects it contains. Therefore, knowing the concepts related to biology correctly is } \\
\text { important for the sustainability of the learning process. In this study, it was aimed to determine the conceptual } \\
\text { perceptions and misconceptions of prospective science teachers about photosynthesis. The research using the } \\
\text { case study was carried out in 2020-2021. The study group of the research consists of } 57 \text { pre-service science } \\
\text { teachers studying in the first and fourth year of a state university in Turkey. The structured interview form and } \\
\text { focus group interview form prepared by the researchers were used as data collection tools. As a result of the } \\
\text { research, it was determined that the conceptual perceptions of the pre-service science teachers about the } \\
\text { substances taken from the external environment in the photosynthesis process, photosynthesis products, and the } \\
\text { importance of photosynthesis for the ecosystem were not sufficient. In addition, in the study, it was determined } \\
\text { that pre-service science teachers had misconceptions about the definition of photosynthesis, energy source and } \\
\text { the importance of photosynthesis for the ecosystem. }\end{array}$ \\
\hline
\end{tabular}

Keywords: misconceptions, photosynthesis, pre-service science teacher

\section{INTRODUCTION}

Biology, known as the science of life in its most general definition, is one of the branches of science closest to individuals due to the subjects it contains. For this reason, knowing the concepts related to biology correctly is very important for both education and personal development of individuals (Karakaya et al., 2020). In this context, photosynthesis is an important biological process that ensures the continuity of life in the biosphere. Photosynthesis is a metabolic process, which means synthesis from light. The chloroplasts of plants capture light energy from the sun and convert it into chemical energy stored in sugar and other organic molecules. In photosynthesis, sunlight is used to convert carbon dioxide $\left(\mathrm{CO}_{2}\right)$ and water $\left(\mathrm{H}_{2} \mathrm{O}\right)$ into carbohydrates (a six-carbon sugar, $\left.\mathrm{C}_{6} \mathrm{H}_{12} \mathrm{O}_{6}\right)$ and oxygen gas $\left(\mathrm{O}_{2}\right)$ (Reece et al., 2013; Sadava et al., 2014). Chloroplasts, which are specific to photosynthesizing cells of plants and algae, are organelles that perform photosynthesis (Simon et al., 2017). In addition, some prokaryotes such as algae, some other members of protista, and cyanobacteria also perform photosynthesis. Scientists define photosynthetic organisms as producers of the biosphere (Brooker, 2017; Johnson, 2012; Pahelan, 2018; Reece et al., 2013; Teiz et al., 2018). When the structure of the chloroplast is examined, it is seen that it has a sheath consisting of two membranes. These two membranes surround a dense fluid called the stroma. Within the stroma is a third membrane system, called the thylakoid, consisting of sacs. Chlorophyll, the green pigment that gives leaves their color, is found in the thylakoid membranes of the chloroplast. Grana are the solar cells of the chloroplasts. These structures capture the sun's rays and convert them into chemical energy. The nutritional needs of all living things, including humans, depend on this transformation. People wear clothes made from photosynthesis products such as cotton. The skeleton of most wooden houses and furniture is made of timber. Timber is wood produced by photosynthesizing trees. Even in the material (paper) used in printed textbooks, traces of photosynthesis in plants can be seen. A student learning the process of photosynthesis should think of the chloroplast as a very tiny sugar factory powered by solar energy. The by-product of photosynthesis is oxygen $\left(\mathrm{O}_{2}\right)$ gas released from the pores to the atmosphere (Pahelan, 2018; Reece et al., 2013; Sadava et al., 2014; Simon et al., 2017). The photosynthesis process is summarized in Figure 1. 


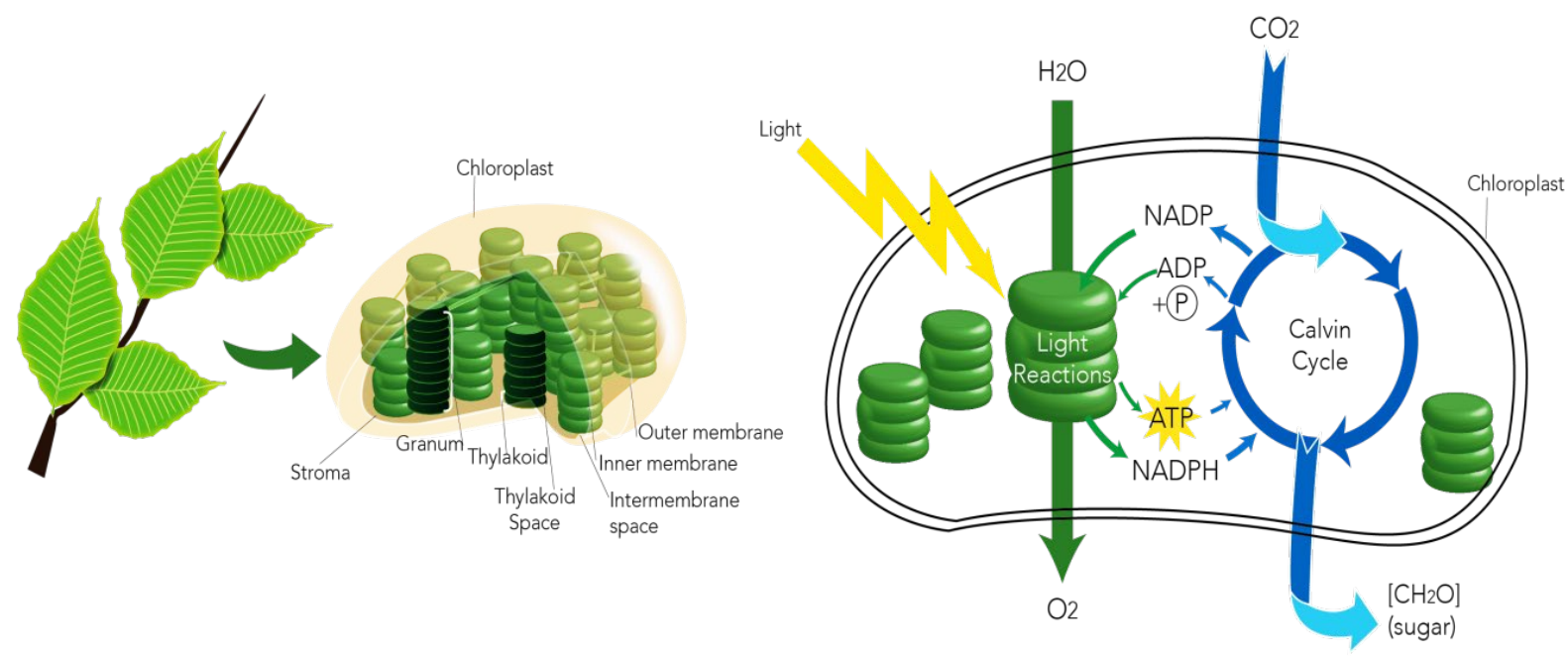

Figure 1. Photosynthesis process (Adapted from Reece et al., 2013)

The complex series of chemical reactions of photosynthesis can be simplified by the following equation:

$$
6 \mathrm{CO}_{2}+12 \mathrm{H}_{2} \mathrm{O}+\text { Light energy } \rightarrow \mathrm{C}_{6} \mathrm{H}_{12} \mathrm{O}_{6}+6 \mathrm{O}_{2}+6 \mathrm{H}_{2} \mathrm{O}
$$

When the Science Curriculum, which is based on the General Objectives of Turkish National Education and the Basic Principles of Turkish National Education, is examined (Ministry of National Education [MoNE], 2018a, p. 52), there are outcomes like "F.8.6.2.1. Realizes the importance of photosynthesis in food production in plants, F.8.6.2.2. Makes inferences about the factors affecting the rate of photosynthesis." In the Biology Course curriculum, "12.2.2.1. Questions the importance of photosynthesis for living things, 12.2.2.2. Explain the photosynthesis process on the diagram and 12.2.2.3. Evaluates the factors affecting the rate of photosynthesis (MoNE, 2018b, p. 30-31)".

Considering that the subject of photosynthesis is included in the biology and science curriculum from secondary school to undergraduate level, prospective teachers who will be active teachers in the education system in the future should have a good command of the subject and should not have misconceptions. Misconceptions are generally defined as unscientific statements learned through experience or by a teacher who has a misconception (Baysen et al., 2012). In other words, misconceptions are the incompatibility between the existing scientific definition of the concepts and the definition created by the students in their own mind (Akgün et al., 2005). Considering that misconceptions emerge in students from an early age and are reinforced during the education-teaching process (Barman et al., 2006), the critical importance of science teachers having sufficient scientific knowledge on photosynthesis is understood. When the literature on the subject is examined, it has been determined that there are some studies (Barrutia \& Díez, 2021; Jayanti, 2020; Kırılmazkaya \& Kırbağ Zengin, 2016; Svandova, 2014; Urey, 2018). For example, in the study conducted by Barrutia and Díez (2021), the conceptual understanding of 7-13 year old students towards plant nutrition was determined using the drawing technique. In the study conducted by Urey (2018), the perceptions and misconceptions of pre-service science teachers about the concept of photosynthesis were determined. As a result of the research, it was determined that the photosynthesis perceptions of the pre-service science teachers differed and they had too many misconceptions. In the study conducted by Svandova (2014), misconceptions of secondary school students regarding the concepts of photosynthesis and respiration in plants were determined. In the research, it was concluded that secondary school students studying in the Czech Republic had too many misconceptions about photosynthesis and plant respiration. In addition, when the literature is examined; It has been determined that there are different studies on teachers, textbooks and supplementary books, which are thought to be effective in the formation of misconceptions (Karakaya et al., 2020a, 2020b; Yılmaz et al., 2017, 2018).

When the general competencies of the teaching profession are examined; It can be said that it is important to train teachers who have field knowledge, inquiring, advanced theoretical, methodological and factual knowledge. Because teachers who have scientifically incomplete or incorrect information will cause their students to fall into the same mistakes (Yilmaz et al., 2021). According to Burgoon et al. (2010), a teacher with misconceptions cannot identify the misconceptions in students and causes new misconceptions to occur. For this reason, it is necessary to determine the perceptions and misconceptions of prospective science teachers about the subjects in the curriculum. In addition, it is important for the sustainability of education systems to eliminate misconceptions with developed guidelines, education models or process-oriented studies. From this point of view, it was aimed to determine how pre-service science teachers perceive the subject of photosynthesis, which aspects of photosynthesis they attach importance to, and misconceptions about photosynthesis. It is thought that the use of drawing technique within the scope of the research, which allows easy comparison at the international level (Prokop \& Fancovicová, 2006) and reflects the mental models of the students (Rybska et al., 2017), will be effective in revealing the conceptual perceptions and misconceptions of preservice science teachers about photosynthesis in detail. 
Table 1. Demographic information of the study group of the research

\begin{tabular}{|c|c|c|c|c|}
\hline Department & Grade Level & Gender & $\mathbf{N}$ & $\%$ \\
\hline \multirow{4}{*}{ Pre- service science teacher } & \multirow{2}{*}{ 1. Grade } & Female & 30 & 53.0 \\
\hline & & Male & 4 & 7.0 \\
\hline & \multirow{2}{*}{ 4. Grade } & Female & 21 & 37.0 \\
\hline & & Male & 2 & 3.0 \\
\hline
\end{tabular}

\section{METHOD}

\section{Research Pattern}

In this study, a case study, one of the qualitative research designs, was used to investigate the conceptual perceptions and misconceptions of pre-service science teachers about photosynthesis in depth and versatile because the case study provides a detailed explanation of the situation or events that occur in a system (Creswell, 2007).

\section{Study Group of the Research}

The study group of this research consists of 57 pre-service science teachers studying in the first and fourth year of a state university in Turkey in the fall semester of the 2020-2021 academic year. In the research, stratified purposive sampling, one of the purposive sampling methods, was used. The selection of a new sample from a determined stratum in line with the purpose of the research is stratified purposive sampling (Johnson \& Christensen, 2008). In addition, purposive samples used in a research can also become stratified and integrated by bringing together different and various purposeful samples (Kerlinger \& Lee, 1999). Firstyear pre-service teachers have been selected to reveal their deficiencies from secondary education as they have just started university education. Fourth grade teacher candidates have been selected because they will complete their university education and start their professional life. Therefore, it is aimed to determine the unchangeable misconceptions of students at both grade levels, both in primary and secondary education, and in undergraduate education. The students to be interviewed were selected from the upper, middle and lower groups, which were formed by looking at the rubric score ranks as a result of the drawing/picture analysis. Groups of six to ten participants are thought to be ideal in focus group interviews (Glesne, 2013, p. 180). Having more than 10 people in the group reduces both the dynamics of the group and the interaction between the participants (Edmunds, 2000). In this study, nine (9) pre-service science teachers participated in the focus interview, three of which were from the upper, middle and lower groups. In terms of ethics of the research, the names of the pre-service teachers participating in the research were kept confidential and codes such as $\mathrm{S} 1, \mathrm{~S} 2, \ldots, \mathrm{S} 9$ were given. The distribution of demographic information of the students participating in the research is given in Table 1.

When the data in Table 1 are examined, $60.0 \%(\mathrm{~N}=34)$ of the pre-service science teachers participating in the research are studying in the 1st grade and $40.0 \%(\mathrm{~N}=23)$ in the 4 th grade. Pre-service teachers studying in the fourth grade were preferred because they will be at the level of completing their undergraduate education and will be working in the education system one year later. Pre-service teachers studying in the first grade were included in the study group with the thought that their secondary education information was up-to-date.

\section{Data Collection Tools}

Within the scope of the research, two different data collection tools (structured interview form and focus group interview form) were used. Data collection tools were developed by the researchers. The opinions of three different field experts (Biology education, Science Education and Measurement-Evaluation) were taken for the validity of the data collection tools and their final forms were created.

\section{Structured interview form}

The model based on drawings and explanations developed by Lampert et al. (2020) enables to reveal the knowledge and misconceptions of individuals. Vygotsky (1967) stated the importance of visual perceptions and stated that children think as if they are explaining that object with words when painting. Similarly, Malchiodi (1998) stated that children's drawings have multiple meanings and reflect many factors. In the literature, it is possible to reach studies that reveal misconceptions by using drawings on different subjects (Çardak, 2015; Taştan-Kırık \& Kaya, 2014;Yörek, 2007). It can be said that the drawing technique is a technique that can be used to understand students' knowledge levels and misconceptions about the subject. As a matter of fact, Köse (2008) reported that drawings can provide important information in identifying misconceptions and are an open-ended tool for creative expression. For this reason, a structured interview form was prepared in order to determine the conceptual perceptions and misconceptions of pre-service science teachers about photosynthesis. Form; It consists of the question "What do you understand by photosynthesis, explain by drawing a picture". The fact that pre-service science teachers explain their knowledge about photosynthesis with drawings helps to identify both correct knowledge and misconceptions.

\section{Focus group interview form}

Malchiodi (2005) stated that one of the best ways to understand children's pictorial expressions is to talk about their pictures. Therefore, a focus group interview was conducted in this research in order to clearly identify the expressions that could not be reflected in the drawing. Thus, it is thought that the meanings that pre-service teachers attribute to their drawings will be revealed more clearly. The key questions in the focus group interview form are given below: 


\begin{tabular}{|c|c|}
\hline 1.Step & $\begin{array}{l}\text { - Opening: Each pre-service teacher introduces } \\
\text { himself/herself within } 60 \text { seconds. }\end{array}$ \\
\hline 2.Step & $\begin{array}{l}\text { - Introductory questions: One or two examples of questions } \\
\text { (A maximum of five minutes of response time is given for } \\
\text { each question). }\end{array}$ \\
\hline 3. Step & -Transition questions: Discussion of one or two questions. \\
\hline 4. Step & $\begin{array}{l}\text { - Key questions: Asking the key questions of the focus } \\
\text { group. }\end{array}$ \\
\hline 5. Step & $\begin{array}{l}\text { - Research questions: Directing one or two research } \\
\text { questions. }\end{array}$ \\
\hline 6. Step & $\begin{array}{l}\text { - Closing question: Asking a final question ( } 3-5 \text { minutes to } \\
\text { answer). }\end{array}$ \\
\hline 7. Step & $\begin{array}{l}\text { - Final question: The steps of asking the participants if there } \\
\text { is a subject that was not mentioned briefly were applied. }\end{array}$ \\
\hline
\end{tabular}

Figure 2. Focus group interview process

\begin{tabular}{|c|c|}
\hline 1.Step & $\begin{array}{l}\text { - Are the photosynthesis products placed correctly in } \\
\text { the drawing? }\end{array}$ \\
\hline 2.Step & $\begin{array}{l}\text { Is the drawing sufficient to summarize } \\
\text { photosynthesis? }\end{array}$ \\
\hline 3.Step & $\begin{array}{l}\text { - Which elements of photosynthesis are given } \\
\text { importance in the drawing? }\end{array}$ \\
\hline 4.Step & - Is the drawing scientifically correct? \\
\hline
\end{tabular}

Figure 3. Instruction steps

- What is photosynthesis?

- What are the substance(s) that photosynthetic organisms must take from the external environment during the photosynthesis process?

- What are the products of photosynthesis?

- What is the importance of photosynthesis for the ecosystem?

\section{Data Collection Process}

In the study, data were collected in two steps to determine the conceptual perceptions and misconceptions of pre-service science teachers about photosynthesis. In the first step, pre-service teachers made drawings on the subject of photosynthesis. In the second step, in order to support the data obtained, focus group interviews were conducted with nine (9) pre-service teachers, taking into account the rubric score orders. The focus group interview process was carried out by considering the implementation process suggested by Krueger (1998). The focus group interview process is given in Figure 2.

\section{Analysis of Data}

Drawings of pre-service science teachers on the subject of photosynthesis; It was analyzed according to the directive created with the opinions of field experts (Biology education, Science Education and Measurement-Evaluation). The steps of instruction used in the analysis of drawings for photosynthesis are given in Figure 3.

The focus group meeting with teacher candidates was held on the Zoom platform due to the Covid-19 pandemic. The audio recordings obtained were transcribed in the computer environment. What matters in reporting the focus group interview is not the numbers, but what the individuals say (Creswell, 2007). For this reason, the views of pre-service teachers were analyzed descriptively in the focus group interview. The answers given by the pre-service teachers to the questions were presented in the form of sentences they used directly, without any changes. The names of the pre-service teachers who participated in the focus group interview were coded as S-1, S-2,..,S-9. In order to avoid data loss in the focus group interview, the answers of the preservice teachers were written by two researchers. The answers given by the pre-service science teachers to the forms were read and coded independently by two researchers, and then the compatibility of these codes was checked. In order to determine 
Table 2. Findings on the correct placement of photosynthesis products in drawings

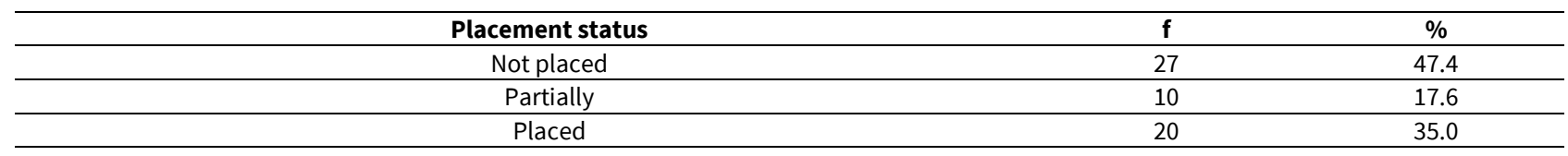

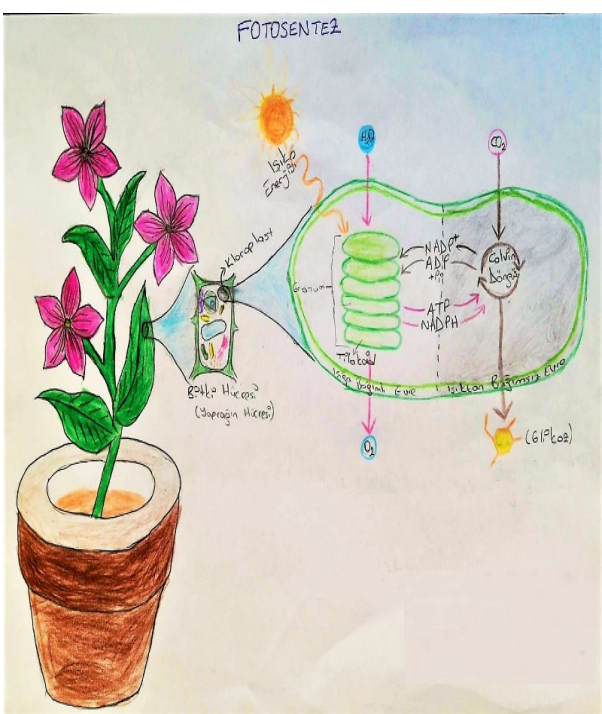

a. Correctly placed

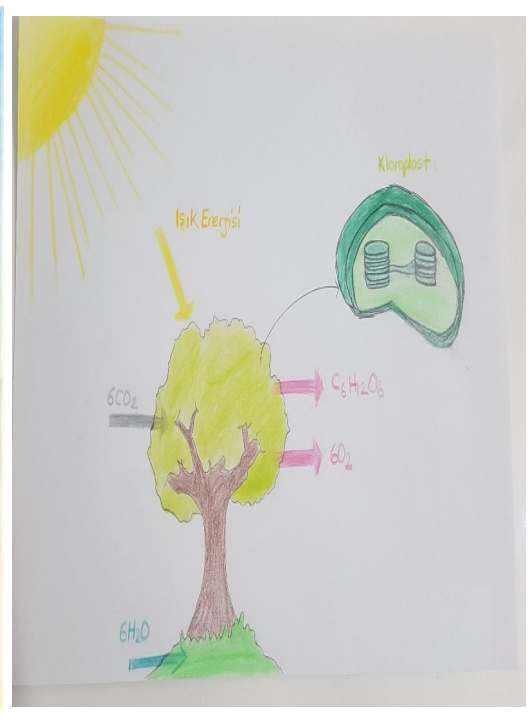

b. Partially placed

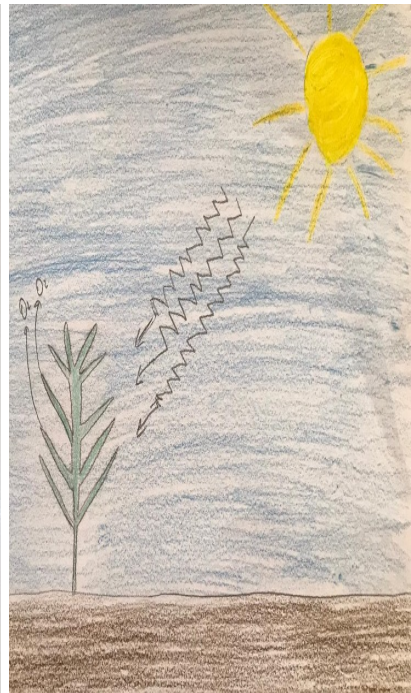

c. Not placed

Figure 4. Examples of drawings for the placement of photosynthesis products

Table 3. Findings for summarizing the subject of photosynthesis

\begin{tabular}{ccc}
\hline Qualification status & f & $\%$ \\
\hline Insufficient & 24 & 42 \\
\hline Partially & 18 & 32 \\
\hline Sufficient & 15 & 26 \\
\hline
\end{tabular}

whether there is consistency among the researchers, the formula (Reliability=Consensus/All opinions) x100, which was put forward by Miles and Huberman (2015), was applied. The reliability value of the two encoders was calculated as $89 \%$.

\section{RESULTS}

Research findings; the findings are presented under two sub-headings as the findings obtained from the drawings of the preservice science teachers and the findings of the focus group interview.

\section{Findings Obtained from the Drawing Directive}

In this section, the findings obtained from the pictures drawn in order to determine the conceptual perceptions and misconceptions of prospective science teachers about photosynthesis are presented. Within the scope of the directive, first of all, "Are the photosynthesis products placed correctly in the drawings of pre-service science teachers?" The answer to the question has been sought. The findings are given in Table 2.

When the findings in Table 2 are examined, $47.4 \%(f=27)$ of the pre-service science teachers participating in the research could not place the photosynthesis products correctly in their drawings, $17.6 \%(f=10)$ partially placed them, and $35.0 \%$ ( $f=20$ ) correctly positioned. Drawing examples for the correct placement of photosynthesis products by pre-service science teachers are given in Figure 4.

When the Figure $\mathbf{4 a}$ is examined, it is seen that the pre-service science teachers correctly placed the plant, leaf, plant cell, chloroplast, granum (thylakoid membranes: light-dependent reactions), stroma (light-independent reactions, CALVIN cycle), incoming and outgoing products. When Figure $\mathbf{4 b}$ is examined, it has not been determined that the visual is very simple in scientific terms and in which part of the plant the chloroplast is located. The chloroplast is simply drawn, but no explanatory information is written on any part of it. When Figure 4c is examined, it was emphasized that light is used in photosynthesis and $\mathrm{O}_{2}$ is released. However, drawing is not at a sufficient level for pre-service science teachers.

Within the scope of the directive, "Are the drawings of pre-service science teachers sufficient to summarize the subject of photosynthesis?" The answer to the question has been sought. The findings are given in Table 3.

When the findings in Table 3 are examined, it is seen that the drawings of $42 \%(f=24)$ of the pre-service science teachers participating in the research are insufficient in summarizing photosynthesis, $32 \%(f=18)$ are partially sufficient and $26 \%(f=15)$ are 


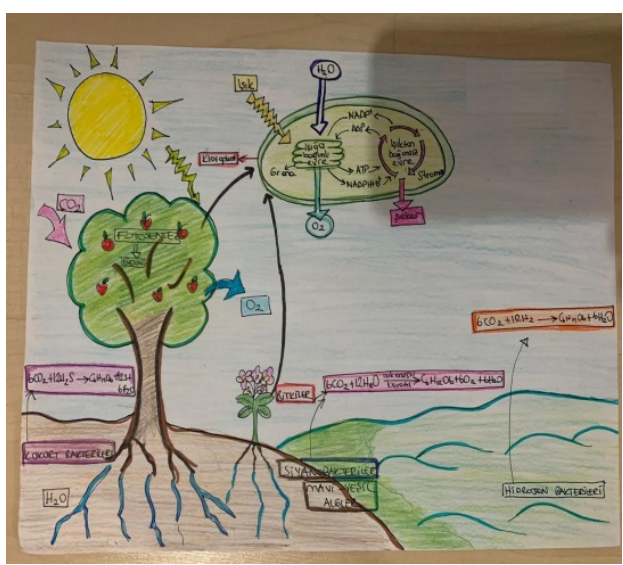

a.Sufficient

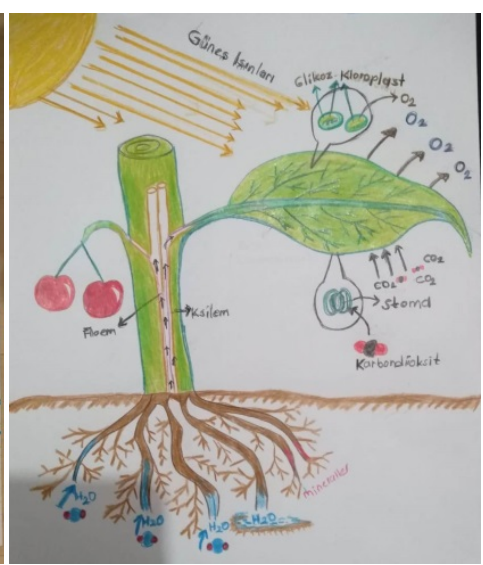

b. Partially Sufficient

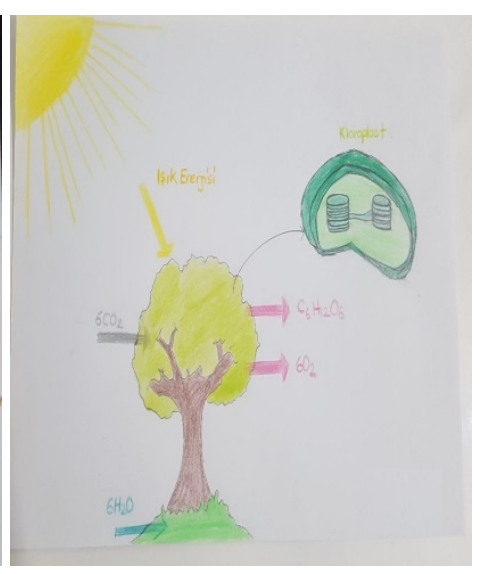

c. Insufficient

Figure 5. Summarization status

Table 4. Findings on the elements of photosynthesis

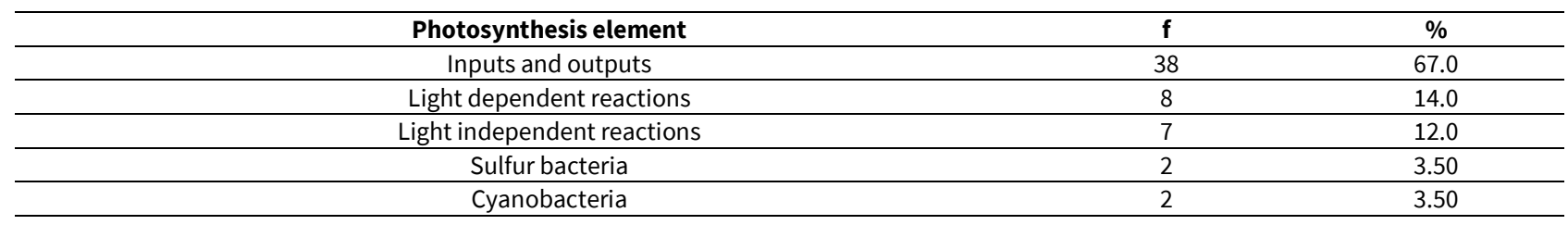

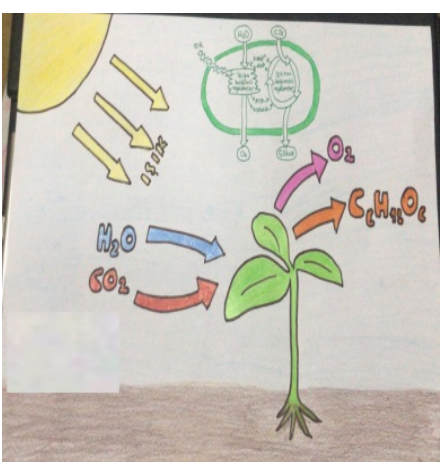

a. Inputs and Outputs

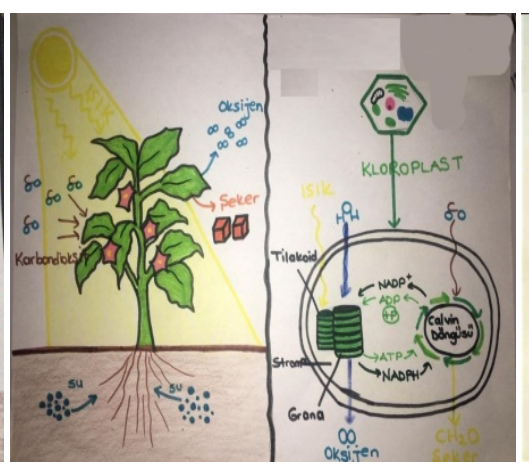

b.Light dependent reactions

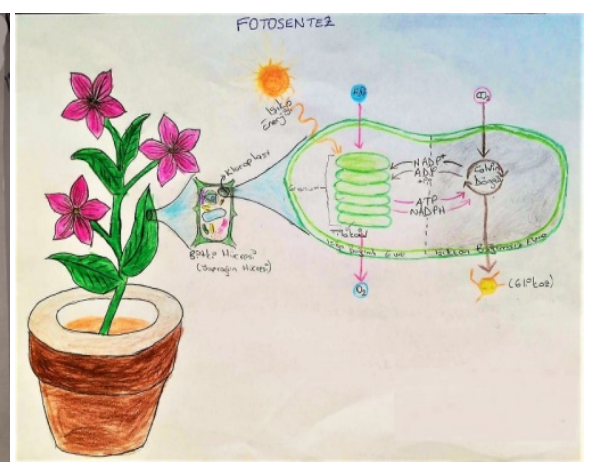

c. Light independent reactions

Figure 6. Photosynthesis elements

determined sufficient. Examples of drawings for pre-service science teachers to summarize the subject of photosynthesis are given in Figure 5.

When Figure $\mathbf{5 a}$ is examined, the photosynthesis that takes place in plants in general and in particular was discussed together with the events in the chloroplast. The main events that take place in the chloroplasts of both trees and herbaceous plants are summarized. The equation of photosynthesis in cyanobacteria is summarized. It differed in terms of the electron sources used. Photosynthesis equations of prokaryotic organisms such as hydrogen bacteria and sulfur bacteria are also expressed in summary boxes. In Figure $\mathbf{5 b}$, inputs and outputs are given. However, drawing is not at a sufficient level for pre-service science teachers.

Within the scope of the directive, "Which element of photosynthesis did pre-service science teachers focus on in their drawings?" The answer to the question has been sought. The findings are given in Table 4.

When the findings in Table 4 are examined, it is seen that $67.0 \%(f=38)$ of the pre-service science teachers who participated in the research have photosynthesis input and output in their drawings, $14.0 \%(f=8)$ light dependent reactions and $12.0 \%(f=8)$ It was determined that they gave importance to light dependent reactions. Drawing samples of pre-service science teachers for the elements of photosynthesis are given in Figure 6.

In Figure $\mathbf{6 a}$, Inputs and outputs are given weight. The NADPH molecule is written as NADHP. When Figure $\mathbf{6 b}$ was examined, it was determined that the pre-service science teacher expressed his thoughts by dividing them into two. In the first, he stated the conditions and products necessary for photosynthesis on a plant. In the second, he described the chloroplast structure in a plant cell. He expressed the light-dependent reactions in the thylakoid membranes and the CALVIN cycle in the stroma in terms of incoming and outgoing products. When Figure $6 \mathrm{c}$ is examined; plant, leaf, plant cell, chloroplast, granum (thylakoid membranes: light-dependent reactions), stroma (light-independent reactions, CALVIN cycle), products entering and leaving are shown.

Within the scope of the directive, "Are the drawings of pre-service science teachers scientifically correct?" The answer to the question has been sought. The findings are given in Table 5. 
Table 5. Findings on the scientific accuracy of photosynthesis drawing

\begin{tabular}{cccc}
\hline Scientific accuracy & f & \% & 4 \\
\hline True & 7 & 4 \\
\hline False & 53 & 93 \\
\hline
\end{tabular}

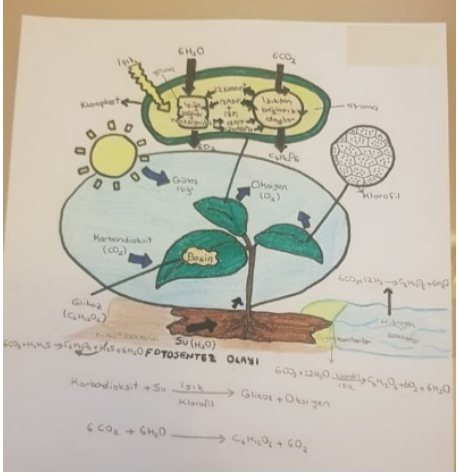

a. Correct drawing

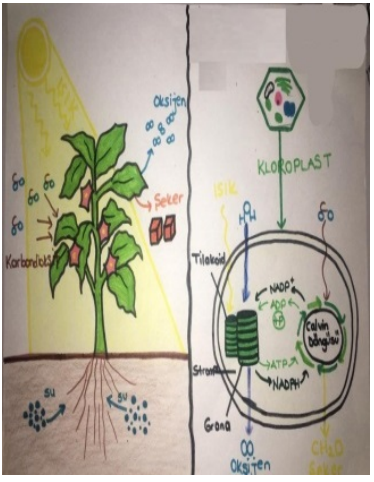

b. Correct drawing

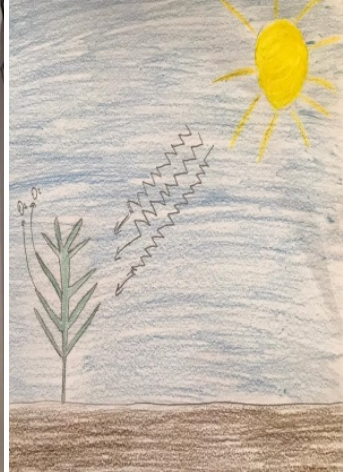

c. Wrong drawing

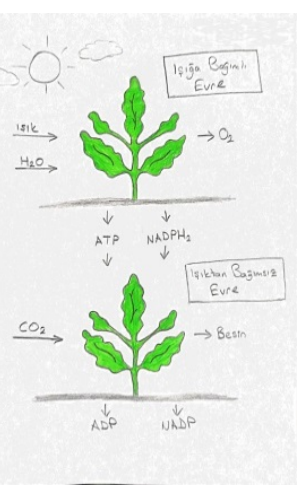

d. Wrong drawing

Figure 7. Scientific status of drawings

Table 6. Findings for the definition of photosynthesis

\begin{tabular}{ll}
\hline Themes & Sample opinions \\
\hline S-1: It can be expressed as the life cycle of plants. \\
S-2: It is the production of oxygen from carbon dioxide. \\
S-3: It is the carbon dioxide and oxygen cycle. \\
S-4: It is the synthesis of organic matter from inorganic substances. \\
S-6: It is the way plants take carbon dioxide and water in a light environment and release nutrients and oxygen. \\
S-7: I can say that plants use light energy to produce the energy necessary for their own metabolism. \\
S-8: It refers to the conversion of inorganic substances into organic substances by using carbon dioxide and water. \\
S-9: The ability of plants to extract organic matter from inorganic substances using light.
\end{tabular}

When the findings in Table 5 were examined, it was determined that the drawings of $7.0 \%(f=4)$ of the pre-service science teachers participating in the study were scientifically correct, while the drawings of $93.0 \%(f=53)$ were incorrect. Examples of drawings for the scientific accuracy of photosynthesis are given in Figure 7.

Figure $7 \mathrm{a}$ is a correct drawing: He evaluated the photosynthesis events in various living things in terms of input and product variety. Plants: leaf, chloroplast, grana (light dependent reactions), stroma (light independent events, inputs and outputs. Figure $\mathbf{7 b}$ is a correct drawing: He expressed his thought by dividing it into two. In the first, he specified the conditions and products necessary for photosynthesis on a plant. In the second, he described the chloroplast structure in a plant cell. He expressed the light-dependent reactions in the thylakoid membranes and the CALVIN cycle in the stroma in terms of incoming and outgoing products. Figure $7 \mathrm{c}$ is a wrong drawing: It is emphasized that light is used in photosynthesis and $\mathrm{O}_{2}$ is released. However, the drawing is far below the knowledge level of the pre-service teacher. Figure $\mathbf{7 d}$ is a wrong drawing: Only the general plant shape was drawn and the conditions and products were sufficient for light dependent and light independent reactions.

\section{Findings Obtained from the Focus Group Discussion}

Within the scope of the research, a focus group interview was conducted in order to determine in detail the conceptual perceptions and misconceptions of pre-service science teachers about the subject of photosynthesis. In the study, it was determined how pre-service science teachers defined the concept of photosynthesis. The findings are given in Table 6 .

When the findings in Table 6 are examined, it was determined that teacher candidates participating in the research defined the photosynthesis of the science as a life cycle, food production and an event realized using light.

In the research, the thoughts (knowledge/perceptions) of the pre-service science teachers about which substances that photosynthetic organisms should take from the external environment during the photosynthesis process were determined. The findings are given in Table 7. 
Table 7. Findings on substances taken from the external environment during the photosynthesis process

\begin{tabular}{ll}
\hline Themes & Sample opinions \\
\hline \multirow{2}{*}{ Carbon dioxide, light, water } & S-3: Carbon dioxide, water and light \\
& S-4: Water, carbon dioxide and light \\
& S-5: Plants take in carbon dioxide, they get light. \\
& S-6: Light, water and carbon dioxide. \\
\hline Carbon dioxide, light, water, mineral & S-2: Sunlight, carbon dioxide, water, minerals \\
\hline Carbon dioxide water and mineral & S-1: Carbon dioxide water and minerals \\
\hline Hight, water, oxygen & S-9: Light, water, oxygen \\
\hline \multirow{2}{*}{ Hydrogen sulfide } & S-3: As far as I remember photosynthesis, I know that some take hydrogen sulfide as well. \\
\hline
\end{tabular}

Table 8. Findings for photosynthesis products

\begin{tabular}{ll}
\hline Themes & Sample opinions \\
\hline \multirow{3}{*}{ Food, oxygen } & S-2: Food, oxygen. \\
& S-7: Gnow as $\mathrm{C}_{6} \mathrm{H}_{12} \mathrm{O}_{6}$ ve $\mathrm{O}_{2}$. \\
& S-8: There was oxygen, glucose as far as I know, food I guess. \\
\hline Food, oxygen, water & S-3: Nutrients, oxygen and in some cases water can also be released. \\
\hline
\end{tabular}

Table 9. Findings on the importance of photosynthesis for the ecosystem

\begin{tabular}{ll}
\hline Themes & Sample opinions \\
\hline S-1: It provides oxygen and carbon dioxide cycles. \\
S-2: It cleans the polluted air. It provides oxygen continuity. \\
S-3: I think in this way, it is necessary to maintain the balance of carbon dioxide and oxygen. \\
S-4: It cleans the air as it takes carbon dioxide in the environment and turns it into oxygen. \\
S-5: It provides the substance cycle for other living things, contributes to the nitrogen cycle and contributes to \\
the water cycle. \\
S-6: Necessary for maintaining balance. \\
S-7: Plants take part in the material cycle because they photosynthesize and are producers. \\
S-1: It is the life cycle. \\
S-6: It is both important for the life of plants and necessary for the continuation of all life. \\
S-7: It is vital for all living things. \\
S-9: They ensure the continuation of other living things. \\
S-8: It is a source of life for photosynthetic organisms. \\
S-4: In photosynthesis, the plant produces its own food. \\
S-5: They also produce food for other living things. \\
S-6: Producers produce food for all living things through photosynthesis. \\
S-7: Plants are in the food chain. \\
S-9: They produce food by obtaining organic matter from inorganic materials.
\end{tabular}

When the findings in Table 7 are examined, the teacher candidates participating in the research expressed their thoughts on the substances that photosynthesizing organisms should take from the external environment during the photosynthesis process as "carbon dioxide, light, water", carbon dioxide, light, water, mineral", "carbon dioxide, water, mineral", "light, water, oxygen" and "hydrogen sulfide".

In the research, pre-service science teachers' thoughts (knowledge/perceptions) about photosynthesis products were determined. The findings are given in Table 8.

When the findings in Table 8 were examined, it was determined that the pre-service science teachers participating in the research defined "food, oxygen" and "food, oxygen, water" as photosynthesis products.

In the study, pre-service science teachers' thoughts (knowledge/perceptions) about the importance of photosynthesis for the ecosystem were determined. The findings are given in Table 9.

When the findings in Table 9 are examined, the pre-service science teachers participating in the research stated the importance of photosynthesis for the ecosystem; matter cycle, life cycle and food production.

\section{DISCUSSION AND CONCLUSION}

In this study, it was aimed to determine the conceptual perceptions and misconceptions of prospective science teachers about photosynthesis. In line with the purpose of the research, pre-service science teachers were asked to make a drawing describing photosynthesis. As a result of the analysis of the photosynthesis drawings of the pre-service science teachers, it was determined that the majority of them could not place the photosynthesis products correctly, and the pictures they drew were insufficient to summarize photosynthesis. In addition, it was determined that pre-service science teachers gave importance to inputs and outputs in photosynthesis and made the photosynthesis drawing scientifically incorrect. According to these results, it can be said that the conceptual perceptions of pre-service science teachers about photosynthesis are not sufficient. When the literature is 
examined, it is seen that there are studies that show similarities with the results of the research. In the study conducted by Köse (2008), it was determined that students' conceptual understanding in their drawings was weak, especially in plants' photosynthesis, respiration, the relationship between photosynthesis and respiration, nutrition of plants, autotrophy and the role of leaves. As a result of the focus group meeting held within the scope of the research, it was determined that the conceptual perceptions of the pre-service science teachers about the substances taken from the external environment in the photosynthesis process, photosynthesis products, and the importance of photosynthesis for the ecosystem were not sufficient. It was concluded that pre-service science teachers integrated photosynthesis only into plants and could not make conceptual explanations about other organisms. In addition, as a result of the research, it was determined that the pre-service science teachers had misconceptions about the definition of photosynthesis, energy source and the importance of photosynthesis for the ecosystem. When the literature on the subject is examined, it has been determined that there are studies that are similar to the findings of the research. For example, in the study conducted by Siyah et al. (2020), it was concluded that students explained the definitions of photosynthesis with the wrong ideas they acquired from daily life such as respiration by plants, taking carbon dioxide in the morning and giving off oxygen, and taking oxygen and giving carbon dioxide in the evening. In addition, it was concluded that most of the students had the idea that photosynthesis takes place only in leaves. Ürey (2018) found in his research that pre-service teachers have the misconception that higher plants can photosynthesize, and only a small percentage (6.0\%) ignores photosynthetic bacteria and algae. Similarly, Tekkaya and Balcı (2003) concluded in their research that the students did photosynthesis to produce oxygen and they could not perceive that oxygen was a by-product. In addition, as the class level increases, it has been determined that they use concepts such as energy change, conversion of light energy into chemical energy, glucose, inorganic and organic, as well as concepts such as sunlight, oxygen, carbon dioxide, water, chlorophyll and nutrients in the definition of photosynthesis (Tekkaya \& Balcı, 2003). Kırılmazkaya and Kırbağ Zengin (2016) concluded that pre-service teachers had misconceptions in the themes of photosynthesis rate, time/place of photosynthesis, definition of photosynthesis and products formed as a result of photosynthesis. In the study conducted by Akçay (2017), it was stated that pre-service science teachers had a weak understanding of energy flow, matter cycle and cellular energy flow, while they had a strong understanding of the concept of respiration and photosynthesis. In addition, it was determined that pre-service teachers had misconceptions about the relationship between the inputs and outputs of photosynthesis and cellular respiration processes (Akçay, 2017). Studies have shown that photosynthesis and respiration events are related to the concept of energy and students have misconceptions (Cocadar, 2012; Lin \& Hu 2003; Özay \& Öztaş, 2010). Brown and Schwartz (2009) stated that although pre-service teachers could write the formulas of photosynthesis and cellular respiration processes, they had difficulty in expressing the connection between these two concepts in terms of energy and matter cycle. Espinoza et al. (2020) stated that it is difficult for students to grasp because most of the biological phenomena, including energy conversion processes, are invisible. Eisen and Stavy (1998) stated that understanding the concepts involved in photosynthesis facilitates the understanding of the relationship between organisms in ecosystems. Similarly, in this study, it was determined that pre-service science teachers emphasized the importance of photosynthesis for the ecosystem, while emphasizing the concepts of matter cycle, life cycle and food production.

One of the remarkable and important results of the research is that pre-service science teachers do not have sufficient field knowledge about scientific concepts related to photosynthesis. Regarding the photosynthesis phenomenon, it was determined that the pre-service science teachers could not generally express the incoming and outgoing products in their drawings. It was determined that pre-service science teachers did not know which part of the plant the chloroplast was in, and they thought that $\mathrm{NADPH}$ was used in both light-dependent and light-independent reactions. In addition, it was determined that pre-service science teachers had misconceptions such as not showing $\mathrm{CO}_{2}$ in the light-independent phase, not specifying the names of the structures in the chloroplast, and showing oxygen as both molecular $\left.\mathrm{O}_{2}\right)$ and atomic $(\mathrm{O})$ outputs. Considering that misconceptions exist throughout the education period from primary school to university, it is worrying that candidates who will start their careers are still misled. Because, just as candidates are expected to teach when they become teachers, they should be taught in the same way at the faculty. This situation supports the fact that teachers are cited as one of the reasons for the misconceptions of students in the literature (Karakaya et al., 2020a, 2020b; Sander, 1993; Yılmaz et al., 2017). As a matter of fact, Ecevit and Özdemir Şimşek (2017) stated in their research that teachers have difficulties in changing their misconceptions about photosynthesis. Studies have shown that these misconceptions stem from the fact that students only memorize the photosynthesis formula (Tekkaya \& BalcI, 2003) and that not learning chemical equations correctly may lead to misconceptions (Cocadar, 2012).

\section{SUGGESTIONS}

Based on the findings of this study, the following recommendations were made:

- In this study, it was understood that the lack of knowledge and misconceptions about photosynthesis in teacher candidates were based on a very long learning process. In order to eliminate these, scientific misconceptions should be tried to be eliminated by applying individual teaching programs rather than classical teaching approaches.

- It was determined that the scientific knowledge level of most of the teacher candidates about the concept of photosynthesis is very insufficient. By going back from the classes they are currently studying, studies can be carried out to determine where their knowledge deficiencies and misconceptions are based.

Author contributions: All authors have sufficiently contributed to the study, and agreed with the results and conclusions.

Funding: No funding source is reported for this study.

Declaration of interest: No conflict of interest is declared by authors. 


\section{REFERENCES}

Akçay, S. (2017). Prospective elementary science teachers' understanding of photosynthesis and cellular respiration in the context of multiple biological levels as nested systems. Journal of Biological Education, 51(1), 52-65. https://doi.org/10.1080/00219266.2016.1170067

Akgün, A., Gönen, S., \& Yılmaz, A. (2005). Misconceptions of preservice science teachers regarding the structure and conductiviiy of mixtures. Hacettepe Üniversitesi Eğitim Fakültesi Dergisi, $28(28), \quad 1-8$. https://dergipark.org.tr/en/pub/hunefd/issue/7808/102414

Barman, C. R., Stein, M., McNair, S., \& Barman, N. S. (2006). Students' ideas about plants \& plant growth. The American Biology Teacher, 68(2), 73-79. https://doi.org/10.2307/4451935

Barrutia, O., \& Díez, J.R. (2021). 7 to 13-year-old students' conceptual understanding of plant nutrition: should we be concerned about elementary teachers' instruction?. Journal of Biological Education, 55(2), $196-216$. https://doi.org/10.1080/00219266.2019.1679655

Baysen, E., Güneyli, A., \& Baysen, F. (2012). Teaching \& learning concepts and misconceptions: science and Turkish teaching cases. International Journal of New Trends in Arts, Sports \& Science Education (IJTASE), 1(2), $108-117$. http://www.ijtase.net/ojs/index.php/IJTASE/article/view/58/72

Brooker, R. J., Widmaier, E. P., Graham, L. E., \& Stiling, P. D. (2017). Biology. McGraw-Hill Education.

Brown, M. H., \& Schwartz, R. S. (2009). Connecting photosynthesis and cellular respiration: preservice teachers' conceptions. Journal of Research in Science Teaching 46(7), 791-812. https://doi.org/10.1002/tea.20287

Burgoon, J. N., Heddle, M. L., \& Duran, E. (2010). Re-examining the Similarities between teacher and student conceptions about physical science. Journal of Science Teacher Education 21(7) 859-872. https://doi.org/10.1007/s10972-009-9177-0

Creswell, J. W. (2007). Qualitative inquiry and research design: Choosing among five approaches. Sage.

Çardak, O. (2015). Student science teachers' ideas of the digestive system. Journal of Education and Training Studies, 3(5), 127-133. https://doi.org/10.11114/jets.v3i5.912

Çokadar, H. (2012). Photosynthesis and respiration processes: Prospective teachers' conception levels. Education and Science, 37(164), 81-93. http://egitimvebilim.ted.org.tr/index.php/EB/article/view/391

Ecevit, T., \& Özdemir Şimşek, P. (2017). The evaluation of teachers' science concept teaching and their action to diagnose and eliminate misconceptions. Ilkögretim Online Dergisi, 16(1), 129-150. https://doi.org/10.17051/io.2017.47449

Edmunds, H. (2000). The focus group research handbook. McGraw-Hill.

Eisen, Y., \& Stavy R. (1988). Students' understanding of photosynthesis. The American Biology Teacher, 50(4), $209-212$. https://doi.org/10.2307/4448710

Espinoza, C., Orvis, K. S., \& Brophy, S. P. (2020). Learning the electron transport chain process in photosynthesis using video and serious game. Journal of Biological Education, 1-21. https://doi.org/10.1080/00219266.2020.1808511

Glesne, C. (2013). Nitel araştırmaya giriş [Introduction to qualitative research] (2nd Ed., A. Ersoy \& P. Yalçınoğlu, Trans., Eds.). Anı Pub.

Jayanti, P. (2020). Comparatıve study: misconceptıons on photosyntheis and respiration concepts from past to the present. JPPS (Jurnal Penelitian Pendidikan Sains), 9(1), 1750-1755. https://doi.org/10.26740/jpps.v9n1.p1750-1755

Johnson, B., \& Christensen, L. (2008). Educational research: Quantitative, qualitative, and mixed approaches. Sage.

Johnson, G. B. (2012). The Living World. McGraw-Hill Companies.

Karakaya, F., Yılmaz, M., Çimen, O., \& Adıgüzel, M. (2020a). Identifying and correcting pre-service teachers' misconceptions about the alternation of generations. Cumhuriyet International Journal of Education, 9(4), $1047-1063$. https://doi.org/10.30703/cije.654967

Karakaya, F., Yılmaz, M., Çimen, O., \& Adıgüzel, M. (2020b). Identifying andcorrecting pre-service teachers' misconceptions about parthenogenesis. Başkent University Journal of Education, http://buje.baskent.edu.tr/index.php/buje/article/view/236

Kerlinger, F. N., \& Lee, H. B. (1999). Foundations of behavioral research. Harcourt College Publishers.

Kırılmazkaya, G., \& Kırbağ Zengin, F. (2016). Determination of photosynthesis misconceptions' through Vee diyagrams and preservice teachers' views towards these tool. Erzincan Üniversitesi Eğitim Fakültesi Dergisi, 18(2), $1537-1563$. https://doi.org/10.17556/jef.70209

Köse, S. (2008). Diagnosing student misconceptions: using drawings as a research method. World Applied Sciences Journal, 3(2), 283-293.

Lampert, P., Müllner, B., Pany, P., Scheuch, M., \& Kiehn, M. (2020). Students' conceptions of plant reproduction processes This paper was presented at the ERIDOB conference 2020. Journal of Biological Education, 54(2), $213-223$. https://doi.org/10.1080/00219266.2020.1739424

Lin, C.Y., \& Hu, R. (2003) Students' understanding of energy flow and matter cycling in the context of the food chain, photosynthesis, and respiration, International Journal of Science Education, 25(12), $1529-1544$. https://doi.org/10.1080/0950069032000052045 
Malchiodi, C. A. (1998). Understanding children's drawings. Guilford Press.

Malchiodi, C. A. (2005). Cocukların resimlerini anlamak [Understanding children's drawings]. Epsilon Pub.

Miles, M.B., \& Huberman, A.M. (2015). Nitel veri analizi [Qualitative data analysis] (1st Ed.) (S. Altun Akbaba \& A. Ersoy, Trans., Eds.). Pegem Academy.

Ministry of National Education [MoNE] (2018a). Fen Bilimleri Dersi Öğretim Programı (ilkokul ve Ortaokul 3,4,5,6,7 ve 8. sınıflar) [Science Curriculum (Primary and Secondary School 3,4,5,6,7 and 8th grades)]. http://mufredat.meb.gov.tr/ProgramDetay.aspx?PID=325

Ministry of National Education [MoNE] (2018b). Ortaöğretim Biyoloji Dersi Öğretim Programı (9, 10, 11, ve 12. Sınıflar) [Secondary Education Biology Curriculum (Grades 9, 10, 11, and 12)]. http://mufredat.meb.gov.tr/Dosyalar/20182215535566Biyoloji\%20d\%C3\%B6p.pdf

Özay, E., \& Öztaş, H. (2010). Secondary students' interpretations of photosynthesis and plant nutrition. Journal of Biological Education, 37, 68-70. https://doi.org/10.1080/00219266.2003.9655853

Pahelan, J. (2018). What Is life? A guide to biology. W. H. Freeman and Company.

Prokop, P., \& J. Fancovicová. (2006). Students' Ideas about the human body: Do they really draw what they know? Journal of Baltic Science Education 2(10), 86-95.

Reece, J. B., Urry, L. A., Cain, M. L., Wasserman, S. A., Minorsky, P. V., \& Jackson, R. B. (2013). Campbell biyoloji [Campbell biology] (E. Gündüz \& I. Türkan, Trans., Eds.). Palme Pub.

Rybska, E., Tunnicliffe, S. D., \& Sajkowska, Z. A. (2017). Children's ideas about the internal structure of trees: Cross-age studies. Journal of Biological Education, 51(4), 375-390. https://doi.org/10.1080/00219266.2016.1257500

Sadava, D., Hillis, M. D., Heller, H. C., \& Berenbaum, M. R. (2014). Yaşam bilimi biyoloji [Life science biology] (E. Gündüz \& I. Türkan, Trans., Eds.). Palme Pub.

Sanders, M. (1993). Erroneous ideas about respiration: The teacher factor. Journal of Research in Science Teaching, 30(8), 919-934. https://doi.org/10.1002/tea.3660300809

Simon, E. J., Dickey, J. L., Hogan, K. A., \& Reece, J. B. (2017). Campbell temel biyoloji [Campbell basic biology] (E. Gündüz \&I. Türkan, Trans., Eds.). Palme Pub.

Siyah, B., Yiğit, N., \& Mazlum Güven, E. (2020). The effect of scientific argumentation on students' understanding of photosynthesis and respiration concepts. Hacettepe Üniversitesi Eğitim Fakültesi Dergisi. Advance online publication. https://doi.org/10.16986/HUJE.2020064478

Svandova, K. (2014). Secondary school students' misconceptions about photosynthesis and plant respiration: Preliminary results. Eurasia Journal of Mathematics, Science and Technology Education, 10(1), 59-67. https://doi.org/10.12973/eurasia.2014.1018a

Taiz, L., Zeiger, E., Møller, I. M., \& Murphy, A. (2018). Plant physiology and development. Sinauer Associates.

Taştan-Kırık, Ö., \& Kaya, H. (2014). A qualitative study concerning the 6th grade students' conceptual structures about the cell concept. International Online Journal of Educational Sciences, 6(3), 737-760. https://doi.org/10.15345/iojes.2014.03.018

Tekkaya, C., \& Balcı, S. (2003). Determination of students' misconceptions concerning photosynthesis and respiration in plants. Hacettepe Üniversitesi Eğitim Fakültesi Dergisi, 24, 101-107.

Urey, M. (2018). Defining the relationship between the perceptions and the misconceptions about Photosynthesis topic of the preservice science teachers. European Journal of Educational Research, 7(4), 813-826. https://doi.org/10.12973/eujer.7.4.813

Vygotsky, L. S. (1967). Play and its role in the mental development of the child. Soviet Psychology 5, 6-18. https://doi.org/10.2753/RP01061-040505036

Waheed, T., \& Lucas A. M. (1992). Understanding interrelated topics: Photosynthesis at age 14+. Journal of Biological Education, 26(3), 193-200. https://doi.org/10.1080/00219266.1992.9655272

Yılmaz, M., Gündüz, E., Çimen, O., \& Karakaya, F. (2017). Examining of biology subjects in the science textbook for grade 7 regarding scientific content. Turkish Journal of Education, 6(3), 128-142. https://doi.org/10.19128/turje.318064

Yılmaz, M., Gündüz, E., Üçüncü, G., Karakaya, F., \& Çimen, O. (2018). Investigation of the biology subjects in eighth grade science textbook in terms of scientific content. Anadolu Öğretmen Dergisi, 2(2), 1-16. https://dergipark.org.tr/tr/pub/aod/issue/41228/490889

Yılmaz, M., Karakaya, F., Çimen, O., \& Adıgüzel, M. (2021). Examining the concept complexity of pre-service teachers in terms of species diversity and species richness. Erzincan Üniversitesi Eğitim Fakültesi Dergisi, 23(1), 1-13. https://doi.org/10.17556/erziefd.524708

Yörek, N. (2007). Determination of student conceptual understanding of cell using student drawings at grades 9 and 11 . Dokuz Eylül Üniversitesi Buca Eğitim Fakültesi Dergisi, 22, 107-114. https://dergipark.org.tr/en/pub/deubefd/issue/25429/268297 